Egypt. Poult. Sci. Vol. (41) (III): (643-658) (2021)

http://www.epsj.journals.ekb.eg/

ISSN: 1110-5623 (Print) - 2090-0570 (Online)

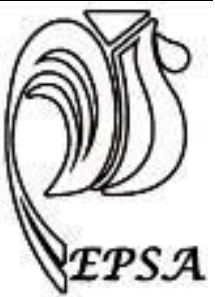

\title{
EFFECT OF MELITTIN AND THEPAX AS NATURAL ALTERNATIVES TO TRADITIONAL ANTIMICROBIAL AND ANTIVIRAL TREATMENTS ON BROILER PERFORMANCE AND SOME RELATED TRAITS
}

M. A., Elmalky; M. O., Taher; A. A., Elsebai; M. H., Khalil; and A. M., Safwat* Poult. Prod. Dep., Fac. of Agric. (El-Shatby), Alexandria Uni., Alexandria, Egypt Corresponding author: A. M., Safwat; E-mail: assemsafwat2004@yahoo.com Received: 02/09/2021 Accepted: $27 / 09 / 2021$

ABSTRACT: The present study was performed to evaluate the untraditional natural additives (Melittin and Thepax) as prospective alternatives to classical therapy treatment through studying their effects on productive performance, carcass characteristics, meat composition and economic efficiency of broiler chicks. A total of 810 one-day old chicks, were randomly distributed into nine experimental groups of 90 birds in three replicates. The experimental treatments were: T1 $=$ Control, T2 $=$ Melittin $(83.3 \mu \mathrm{g} / \mathrm{L})$, T3= Melittin $(166.6 \mu \mathrm{g} / \mathrm{L}), \mathrm{T} 4=$ Thepax $(0.25 \mathrm{~g} / \mathrm{kg})$, T5= Thepax $(0.5 \mathrm{~g} / \mathrm{kg}), \mathrm{T} 6=$ Melittin $(83.3 \mu \mathrm{g} / \mathrm{L})+$ Thepax $(0.25 \mathrm{~g} / \mathrm{kg}), \mathrm{T} 7=$ Melittin $(166.6 \mu \mathrm{g} / \mathrm{L})+$ Thepax $(0.25$ $\mathrm{g} / \mathrm{kg}), \mathrm{T} 8=$ Melittin $(83.3 \mu \mathrm{g} / \mathrm{L})+$ Thepax $(0.5 \mathrm{~g} / \mathrm{kg}), \mathrm{T} 9=$ Melittin $(166.6 \mu \mathrm{g} / \mathrm{L})+$ Thepax $(0.5 \mathrm{~g} / \mathrm{kg})$. The results revealed that the highest BW and BWG were achieved by birds of T6 and T7 (with 8.84, 7.97\% and 9.05, 8.13\% higher than the control group, respectively). Moreover, birds treated with the various combinations of Thepax and Melittin (T6, T7, T8, and T9) had significantly the best FCR values (with $10.38 \%$ improvement, on average, compared to the control group). The same previous groups had significantly the lowest mortality rates. Birds of T6 recorded the highest European production efficiency factor being 376.73. Additionally, broilers treated with various combinations of Melittin and Thepax had significantly the highest carcass weight with the lowest abdominal fat percentages. It could be observed also that birds treated with higher Melittin level (T3, T7 or T9 groups) had significantly the lowest breast protein percentages and the highest fat composition. Finally, broilers of T6 obtained the best economic efficiency value. In conclusion, supplementing broilers with $83.3 \mu \mathrm{g}$ Melittin $/ \mathrm{L}$ water $+0.25 \mathrm{~g}$ Thepax $/ \mathrm{kg}$ feed could be used to replace the classical veterinary treatments, that provides beneficial effects on productive performance, health status, and carcass quality of broilers with improving the economic efficiency of broiler production.

Key words: Melittin, Thepax, Productive performance, Carcass quality, Broilers. 
M. A., Elmalky et al.

\section{INTRODUCTION}

Broiler meat is the main source of healthy meal and plays a major role in the economy of countries, especially Egypt. Therefore, in order to achieve high production performance with protection against diseases, antibiotics are used as an antimicrobial growth promoter (AGP); the term of AGP is used to describe any veterinary care that destroys or inhibit bacteria and is administered at a low and sub therapeutic dose for the purpose of performance enhancement. However, prevalence of resistance in animal bacteria and a risk factor for the emergence of antimicrobial resistance in human pathogens and imbalance of normal microflora containing gut were observed (Awad et al., 2009). About 700,000 people are died worldwide each year due to antibiotics resistance as reported by Willyard (2017), so controlling agencies are rejecting the use of these antimicrobial agents that associated with human health endanger (Bolarinwa et al., 2013). For this cause, an emphasis has always been laid on the development of alternatives to reduce the negative effect of antimicrobial drugs on poultry performance. One such candidate of reducing antibiotics programs is antimicrobial peptides (AMPs) which derived from plants, insects, and animals (Wang et al., 2016); these substances work as the first line of host defense against invading microbes (Fox, 2013) because of their promising effect as growth promoter and antibacterial therapeutic agents over the conventional antibiotics (Regmi et al., 2017). In this respect, bee venom comprises such peptides as melittin, apamin, adolapin, and mast-cell-degranulating peptide (Lee et al., 2009). Many studies concerned these additives which have been of growing interest in the use of whole honeybee venom and some of its components, particularly Melittin, which possess antibacterial and non-steroidal anti-inflammatory activities in very small doses involving no side effects in broilers nutrition (Sun et al., 2007 and Han et al., 2010). Another promising method of reducing antibiotics as growth promoters in broiler diets involves the use of new patent prebiotic inactivated Saccharomyces cerevisiae Var. ellipsoideus (Thepax $\left.{ }^{\circledR}\right)$ to produce healthy chicken products for human consumption. The present study was designed to evaluate the potential effect of including two levels of either Melittin via drinking water or Thepax ${ }^{\circledR}$ as a commercial additive via the formulated diet and their combinations as alternatives to commercial antimicrobial and antiviral treatments on the productive performance, carcass traits and meat chemical composition. Finally, economic evaluation was also performed for the different studied experimental treatments.

MATERIALS AND METHODS

The experimental work of the present study was carried out at the research station of Poultry Production Department, Faculty of Agriculture, Alexandria University during March to April, 2019.

Birds, treatments, and experimental design:

A total of 810 unsexed one-day-old Ross 308 broiler chicks were purchased from a commercial hatchery, they were randomly distributed on 9 experimental groups; each group had 90 broilers arranged in 3 replicates of 30 chicks each. The assembly of each pen included a tube feeder and bell drinker as well as it was provided with appropriate sources of heat, light and ventilation. Chicks were assigned to 9 dietary treatments as follow: 
Melittin, Thepax, Productive performance, Carcass quality, Broilers.

T1: Traditional antimicrobial and antiviral treatments without any of studied additives (control).

T2: Melittin (83.3 $\mu \mathrm{g} / \mathrm{L} \quad$ water $)$ supplementation without therapy treatments.

T3: Melittin (166.6 $\mu \mathrm{g} \quad / \mathrm{L} \quad$ water) supplementation without therapy treatments.

T4: Thepax $\left(\begin{array}{lllll}0.25 & \mathrm{~g} & / \mathrm{kg} & \text { diet }\end{array}\right.$ supplementation without therapy treatments.

T5: Thepax $\left(\begin{array}{llll}0.50 & \mathrm{~g} & / \mathrm{kg} & \text { diet }\end{array}\right)$ supplementation without therapy treatments.

T6: Melittin (83.3 $\mu \mathrm{g} / \mathrm{L}$ water) and Thepax $(0.25 \mathrm{~g} / \mathrm{kg}$ diet $)$ supplementation without therapy treatments.

T7: Melittin (166.6 $\mu \mathrm{g} / \mathrm{L}$ water) and Thepax (0.25 $\mathrm{g} / \mathrm{kg}$ diet) supplementation without therapy treatments.

T8: Melittin (83.3 $\mu \mathrm{g} / \mathrm{L}$ water) and Thepax $(0.50 \mathrm{~g} / \mathrm{kg}$ diet $)$ supplementation without therapy treatments.

T9: Melittin (166.6 $\mu \mathrm{g} / \mathrm{L}$ water) and Thepax $(0.50 \mathrm{~g} / \mathrm{kg}$ diet $)$ supplementation without therapy treatments.

Broilers of the experimental groups were fed on corn-soya bean meal basal diets that was formulated to meet Ross nutrient requirements for starter and growerfinisher growth periods and based on two phase feeding scheme matching starter (1- $21 \mathrm{~d})$ and grower-finisher $(22-35 \mathrm{~d})$. The composition and chemical analyses of the experimental diets are shown in Table (1). Feed and fresh water were provided ad-libitum over the whole experimental growth period.

\section{The identification of studied additives: 1- Lyophilized Melittin:}

Bee venom was obtained from honeybees and collected by the electric shock method according to Mohanny (2005). Melittin separation and purification process was performed on the collected bee venom, as it involves a chain of purification steps, whereby different separation techniques. To achieve an ideal purification of Melittin the cationexchange chromatography was applied according to the method of Schmidt et al. (2014). The identified substances of studied lyophilized Melittin are presented in Table (2)

\section{Thepax:}

Thepax ${ }^{\circledR}$ is the patent new commercial inactivated yeast (Saccharomyces cerevisiae) which obtained from the brewery industry. It contains chitin, mannan oligosaccharide and $\beta$-glucan that have been known as an immune stimulant (Rodriguez et al., 2003).

\section{Performance traits:}

Chicks were individually weighed weekly throughout 5 weeks of experimental period, also feed intake (FI), and mortality rate were determined weekly. Body weight gain (BWG), and feed conversion ratio (FCR) were calculated throughout the experimental period (1-5 weeks of age). At the end of the experiment, European Production Efficiency Factor (EPEF) was calculated by using the equation of Lemme et al. (2006) as follows:

$$
\mathrm{EPEF}=\frac{\text { Viability }(\%) \times \mathrm{BW}(\mathrm{kg})}{\text { Age (d) } \mathrm{FCR}(\mathrm{kg} \text { feed } / \mathrm{kg} \text { gain })} \times 100
$$

In this respect, results of European efficiency index $\geq 300=$ excellent flock, $280-300=$ very good flock, 270-280 = good flock, 260-270 = fair flock, and < $260=$ weak flock.

\section{Slaughter traits:}

At the end of the experimental period ( 35 days), 6 birds from each treatment (total of 54 birds) were selected and individually weighed as pre-slaughter weight. When complete bleeding was achieved, the slaughter weight was 


\section{A., Elmalky et al.}

recorded, then after, the carcass was opened down and all the internal organs (liver, gizzard, heart, spleen, bursa, intestine and abdominal fat) were carefully removed and weighed. The empty carcass was separately weighed, and percentage of empty carcass and organs was calculated based on the preslaughter weight. The applied experimental procedures were ethically reviewed and approved by Institutional Animal Care and Use Committee (IACUC) of Alexandria University.

Chemical composition of breast meat:

Based on dry matter basis, 6 broiler breast meat samples for each studied treatments were used to determine moisture, protein, fat and ash percentages according to procedures of Association of Official Analytical Chemists (A.O.A.C., 2000).

\section{Economic efficiency:}

The price of each $\mathrm{kg}$ of the experimental diets was calculated according to the price of the feed ingredients in the local market at the time of the experiment in addition to the price of Melittin or/and Thepax supplementation. In this respect, cost index, net revenue and relative economic efficiency of one bird were calculated.

\section{Statistical analysis:}

The experimental data were analyzed in a completely randomized design using the General Linear Model (GLM) option of the ANOVA software of SAS program (SAS, 2004). Mean values were compared using Duncan's multiple range test (Duncan, 1955) when significant differences existed. The significance level was set at 5\% and the following statistical model was used:

$\mathrm{Y}_{\mathrm{ij}}=\mu+\mathrm{T}_{\mathrm{i}}+\mathrm{e}_{\mathrm{ij}}$

Where;

$\mu=$ The overall mean,

$\mathrm{T}_{\mathrm{i}}=$ The effect of treatment, $\mathrm{e}_{\mathrm{ij}}=$ Experimental random error.

\section{Performance traits:}

\section{RESULTS}

Data for productive performance traits of broiler chicks supplemented with different inclusion types and levels of non-traditional additives as replacement of commercial antimicrobial and antiviral treatments during the experimental growth periods are displayed in Table (3). The highest $(\mathrm{P}<0.05)$ final $\mathrm{BW}$ (at 35 days of age) and BWG (from 1 - 35 days of age) were associated with birds of T6 and T7. The percentages of those increments in such groups compared to the control one (treated with the systematic medical program) were 8.84 and $7.97 \%$ as well as 9.05 and $8.13 \%$, respectively. Despite the insignificant difference among the experimental groups in feed intake, the unsupplemented control group found to be numerically the highest value of feed intake $(3.201 \mathrm{~kg})$ when compared with the other groups which supplemented with the studied additives. The groups supplemented with either Thepax levels (T4 or T5) along with the control group (T1) had the worst FCR values followed by those supplemented with either Melittin levels (T2 or T3) at the same significance level, while all birds treated with the various combinations of Melittin and Thepax (T6, T7, T8, and T9) had significantly the best FCR values (with $10.38 \%$ improvement, on average, compared to the control group).

It could be noted in Table (3) that all groups supplemented with the various combination levels of Melittin and Thepax (T6, T7, T8, and T9) had recorded the lowest mortality rates $(\mathrm{P}<0.05)$, however the groups supplemented with either level of Thepax (T4 or T5) in addition to those of control 
Melittin, Thepax, Productive performance, Carcass quality, Broilers.

treatment (T1) had significantly the highest rates of mortality. The highest score of EPEF $(\mathrm{P}<0.05)$ was achieved by birds of T6 (with $21.8 \%$ higher than the control group), however birds treated with either the control treatment or T5 significantly obtained the lowest scores of EPEF being 309.31 and 319.44, respectively.

\section{Carcass characteristics:}

The relative weights of carcass and internal organs of broiler chicks as affected by different types and levels of studied non-traditional additives and their combinations at the end of growth period (35 days) are illustrated in Table (4). It is obvious that all treatments with various combination levels of Melittin and Thepax (T6, T7, T8, and T9) significantly increased the relative carcass weight, meanwhile birds of the control group had the lowest relative weight $(\mathrm{P}<0.05)$. The percentages of that increase in such treatment groups compared to the control birds were 5.0, 6.2, 3.8 and $4.3 \%$, respectively. On the contrary, a reverse trend was obtained for the abdominal fat percentage as the previous treatments (T6, T7, T8, and T9) showed significant decrement along with both Melittin treatments (T2 and T3) when compared with those of the control group (T1). It is clear from the obtained data that there was no significant difference among experimental groups regarding liver, gizzard, hart, spleen, or intestine relative weights. Concerning the relative weight of bursa of fabricius; it is clearly shown that all groups treated with the high dosage of Melittin (T3, T7 or T9) had significantly the highest relative weights of bursa $(\mathrm{P}<0.01)$ in comparison to those of un-supplemented group (T1). The percentages of that increments in such treated groups compared to the control group were $61.5,53.8$ and $84.6 \%$, respectively.

\section{Meat chemical composition:}

As shown in Table (5); both moisture and ash percentages of breast meat were not affected by the different studied supplementation treatments $(\mathrm{P}>0.05)$ at 35 days of broiler age. Regarding the protein percentage, it could be observed that the un-supplemented control group (T1) recorded the highest percentage $(\mathrm{P}<0.05)$ in this regard, but all the experimental groups of the high Melittin dosage (T3, T7 or T9) had significantly the lowest protein percentages. Contradictory, such experimental groups (T3, T7 or T9) significantly recorded the highest percentages of fat composition, at the same significant level, whereas the control group along with either Thepax groups (T4 or T5) had the lowest fat composition percentages $(\mathrm{P}<0.05)$.

\section{Economic evaluation of studied experimental treatments:}

It is clearly shown (Table 6) that the least values of feed cost per $\mathrm{kg}$ gain was associated with groups received T6, T8, T2, T4 and T5. Such decrements were $9.3, \quad 7.5, \quad 6.9, \quad 3.6$ and $1.6 \%$ when compared with that of the control, respectively. The opposite was true with treatments of high dose of Melittin (T3, T7 and T9) which recorded the worse results than that of the control group by about 17.0, 10.8 and $14.9 \%$, respectively. Similar results of improvement were recorded for the relative economic efficiency.

\section{DISCUSSION}

The application of synthetic antimicrobial and antiviral treatments in broilers production threatens consumer health, where resistant microbial populations are the outcome of these substances. So, results of the present investigation 


\section{A., Elmalky et al.}

revealed that the improvement of birds treated by $\mathrm{T} 6$ and $\mathrm{T} 7$ was expected; as each of studied products (Melittin and Thepax) was reported to has favorable effects on growth performance and overall health status of broiler chicks (Boostani et al., 2013; Kim et al., 2018), furthermore the mixture of both studied products has a biological additive effect on the performance of broilers. The beneficial effect of this mixture did not extend to T8 and T9; that may be due to the overdose of Thepax than the recommended level of the produced company $(0.25 \mathrm{~g} / \mathrm{kg}$ diet $)$ which may resulted in microbial imbalance of intestinal microflora (Boostani et al., 2013). Also, the cytotoxicity of Melittin limits the amount of Melittin that can be used as growth promoter (Han et al., 2013 and Jamasbi et al., 2014). So, the non-specific toxicity containing Melittin has limited scientific research on its potential effects (Liu et al., 2016). Along the same line, Raghuraman and Chattopadhyay (2007) revealed that the active compound Melittin is haemolytic peptide.

The positive effect of such studied additives on broilers BW and BWG were in agreement with several studies used similar supplementations, in this regard Han et al. (2010) reported that supplementing honeybee venom via drinking water to broiler chicks significantly improved BW especially during the early stage of broilers life that support the potential use of bee venom as an organic alternative to antimicrobial growth promoter. Additionally, Boostani et al. (2013) found that broilers supplemented with Thepax presented significantly higher BW in comparison with the control birds. They regarded the improvement in BW obtained from using that product with prebiotic nature to improve the gut health and performance of the host in the absence of antibiotic growth promoters, as oligosaccharides contributed to stimulate the growth of some beneficial bacteria such as Lactobacillus spp. and Bifidobacterium species (Kim et al., 2011; Abdel-Raheem et al., 2012).

Despite the insignificant difference among the studied treated groups in the FI, birds of the various combinations of Melittin and Thepax (T6, T7, T8, and T9) accomplished the best FCR values, that was as a result of the higher weights gained by such treated groups. In consistence with the obtained results, Kim et al. (2018) found that supplementing broiler chicks with bee venom via drinking water leaded to improve FCR without altering FI, they regarded the improvement in FCR of such treated birds to the enhancement in nutrient utilization occurred by bee venom treatment. Along the same line, Boostani et al. (2013) recorded a significant improvement in FCR of broilers supplemented with Thepax compared with the control treatment, that was because of Thepax supplementation contributed to modify intestinal $\mathrm{pH}$, alter the composition of intestinal flora and their balance as well as enhance nutrient digestibility resulting in improving growth rate and FCR of broiler chicks, as reported by Boostani et al. (2013).

Concerning the mortality rates, the positive results recorded for all groups supplemented with the various combination levels of Melittin and Thepax could be regarded to the synergetic effect of both studied additives on the immunity enhancement. In this regard, Han et al. (2010) recorded significantly lower mortality rate for 
Melittin, Thepax, Productive performance, Carcass quality, Broilers.

broilers drank water supplemented with bee venom compared with the control group. Moreover, Owens and McCracken (2007) demonstrated that dietary yeast supplementation improves the survivability of broiler chicks as yeast stimulates bird's immunity against pathogenic bacteria including Salmonella, E. coli and Clostridium (Ghadban, 2002). Additionally, yeast is a good source of selenium and chromium elements; both trace minerals may have favorable effects on broiler health and immunity (Celik $e t$ al., 2001). Furthermore, Melittin is known to possess strong antimicrobial activity against pathogenic bacteria including Bacillus subtilis, and Pseudomonas aeruginosa (Park et al., 2003). In this regard, we hypothesized that Melittin with the involvement of phospholipase A2 might behave as a chemical promoter at the level of cellular membrane in this study because it induces membrane permeabilization by reorganizing phospholipid assemblies (Raghuraman and Chattopadhyay, 2007) The outstanding results obtained for the European production efficiency factor were in favor of all birds treated with the various combinations of Melittin and Thepax compounds mainly attributed to that mentioned groups had the highest $\mathrm{BW}$, lowest mortality rate and best FCR regardless the fourth limiting factor affecting the equation of the EPEF which is marketing age, as this factor was constant for all experimental treatments (35 days).

The observed improvement for birds treated with various combination levels of Melittin and Thepax could be explained as using both studied substances had beneficial effects on nutrients uptake which resulting in higher synthesis rate of muscle tissues by broilers treated with those additives. This result was in agreement with Boostani et al. (2013) who reported that broilers supplemented with Thepax presented significantly higher carcass weight compared with the other groups. Meanwhile, the positive results of lower abdominal fat percentage associated with the treatments of various combination levels of Melittin and Thepax along with both solely Melittin treated groups might be due to the reduction of acetyl-CoA carboxylase activity which is the limiting enzyme in the synthesis process of fatty acids (Santoso et al., 1995). Moreover, Kannan et al. (2005) indicated that the reduction in abdominal fat pad percent of prebiotics supplemented broilers might be due to maximize energy and fat utilization as a result of increasing the beneficial bacterial population. In accordance with the present results, Midilli et al. (2008) demonstrated that broilers under the prebiotic treatment presented the lowest percentage of abdominal fat pad as compared to the un-supplemented treatments $(\mathrm{P} \leq 0.05)$. The increment in the relative weight of bursa as affected by Melittin supplementation (especially in all groups treated with the high dosage levels) is a good indicator of the immunity enhancement of such treated groups. That result was in a harmony with Rabie et al. (2018) who reported that beevenom treatment, at $2 \mathrm{mg} / \mathrm{L}$ water, resulted in significantly higher relative weight of bursa for broilers compared to the un-supplemented control group.

It has been reported that the higher fat percentage in breast meat tissue leaded to lower protein composition in the tissue and vice versa (Oliveira et al., 2021). The fat deposition in muscles positively affects the meat quality and primarily influence flavor, juiciness, and 


\section{A., Elmalky et al.}

tenderness which finally increases the consumers acceptability (Webb, 2006), conversely higher protein deposition in muscle tissues may increase muscle hardness which partially resulted in wooden breast myopathies (Petracci et $a l ., 2019)$. The higher fat composition and lower protein percentage observed in breast meat of the groups received high Melittin dosage could be explained as Melittin apparently binds to phospholipids making the lipid in the fluid state. Fain et al. (1981) found that Melittin markedly increased intracellular accumulation of lysophospholipids in fibroblasts. Moreover, it has been described that Melittin is an activator of phospholipase A2 which is partly responsible for many of the previous described effects, and it is presented in the commercially available preparations of Melittin (Fain et al., 1981).

The best economic efficiency values achieved by both groups supplemented with the combination of low Melittin level plus high and low level of Thepax was mainly due to the positive effect of studied additives on the BWG with the neglectable effect on FI. Along the same line, Ahiwe et al. (2015) showed that
Baker royal yeast (saccharomyces cerevisae) at $5 \mathrm{~g} / 100 \mathrm{~kg}$ feed as a natural probiotic additive markedly improved the economic gains of broiler chicks. On the other hand, the discouraged results associated with all groups treated with the high level of Melittin, either solely or accompanied with Thepax supplementation levels, may be attributed to the high price of Melittin which leaded to increase the total feed cost of such experimental groups.

\section{CONCLUSION}

A combination of Melittin via drink water and Thepax via formulated diets could be supplemented to broiler chicks as organic non-traditional additives to replace the commercial antimicrobial and antiviral treatments used throughout overall growth period. Such studied additives have synergistic beneficial effects on growth performance, health status, carcass characteristics and meat chemical composition of broilers and hold a considerable promise for the health care aspect. A dosage of $83.3 \mu \mathrm{g}$ Melittin $/ \mathrm{L}$ water $+0.25 \mathrm{~g}$ Thepax $/ \mathrm{kg}$ feed have been found to be economically the best mixture. 
Table (1): Composition and calculated chemical analysis of commercial starter and grower-finisher diets supplied to broilers throughout the experimental growth periods of (1-21) and (22-35) days

\begin{tabular}{|c|c|c|}
\hline \multirow[b]{2}{*}{ Ingredients (kg) } & \multicolumn{2}{|c|}{ Basal experimental diets } \\
\hline & $\begin{array}{l}\text { Starter period } \\
(1-21 \mathrm{~d})\end{array}$ & $\begin{array}{c}\text { Grower-finisher period } \\
(22-35 \text { d })\end{array}$ \\
\hline Yellow corn & 555 & 600 \\
\hline Soya bean meal $46 \%$ & 344 & 290 \\
\hline Corn gluten meal $60 \%$ & 40 & 42 \\
\hline Soya bean oil & 17 & 25 \\
\hline Mono calcium phosphate & 15 & 14 \\
\hline Limestone & 16 & 16 \\
\hline Sodium chloride (Salt) & 3.8 & 3.8 \\
\hline Vit. \& minerals premix* & 3.0 & 3.0 \\
\hline Choline chloride & 1.0 & 1.0 \\
\hline DL-Methionine & 2.7 & 2.5 \\
\hline L-Lysine $\mathrm{Hcl}$ & 2.5 & 2.7 \\
\hline Total & 1000 & 1000 \\
\hline \multicolumn{3}{|l|}{ Calculated analysis: } \\
\hline Crude protein, $\%$ & 23.00 & 21.00 \\
\hline Metabolizable energy, K.cal $/ \mathrm{kg}$ & 3000 & 3100 \\
\hline Ether extract, \% & 4.30 & 5.20 \\
\hline Crude fiber, $\%$ & 2.30 & 2.10 \\
\hline Calcium, \% & 1.00 & 0.96 \\
\hline Available phosphorus, $\%$ & 0.50 & 0.48 \\
\hline Lysine, $\%$ & 1.50 & 1.40 \\
\hline Methionine, \% & 0.69 & 0.64 \\
\hline Methionine + Cystine, $\%$ & 1.00 & 0.99 \\
\hline
\end{tabular}

* Premix supplied per 3 kilograms of diet: Vit. A: 12000000 IU, Vit. E: $10000 \mathrm{mg}$, Vit. B1: $1000 \mathrm{mg}$, Vit. B2: $5000 \mathrm{mg}$, Vit.B6: $1500 \mathrm{mg}$, Vit, B12: $10 \mathrm{mg}$, Niacin: $30000 \mathrm{mg}$, Pantothenic acid: 15000 mg, Vit. K: 2000 mg, Vit. D3; 2200000 IU, Biotin: 50 mg, Folic acid: 1000 mg, Cu: 4000 mg, I: 2000 mg, Fe: 30000 mg, Mn: 60000 mg, Zn: 50000 mg, Se: 400 mg and Co: $100 \mathrm{mg}$. 
Table (2): Principal identified substances of studied lyophilized Melittin product by high performance liquid chromatography (HPLC) analysis

\begin{tabular}{|l|c|c|c|c|}
\hline \multicolumn{1}{|c|}{ Compounds } & $\begin{array}{c}\text { RT } \\
\text { (Minutes) }\end{array}$ & Chemical formula & $\begin{array}{c}\text { MW } \\
\text { (Daltons) }\end{array}$ & $\begin{array}{c}\text { Concentration } \\
\text { (g /100 g DM) }\end{array}$ \\
\hline Melittin & 42.363 & $\mathrm{C}_{131} \mathrm{H}_{22} \mathrm{~N}_{39} \mathrm{O}_{31}$ & 2846.46 & 70.76 \\
Apamine & 46.134 & $\mathrm{C}_{79} \mathrm{H}_{131} \mathrm{~N}_{31} \mathrm{O}_{24} \mathrm{~S}_{4}$ & 2027.34 & 7.48 \\
Phospholipase A2 & 42.363 & $\mathrm{C}_{10} \mathrm{H}_{21} \mathrm{NO}_{8} \mathrm{P}^{+}$ & 14500 & 3.82 \\
\hline
\end{tabular}

$\mathrm{RT}=$ retention time, $\quad \mathrm{MW}=$ molecular weight of the compound

Table (3): Effect of different inclusion types and levels of non-traditional additives as replacement of commercial antimicrobial and antiviral treatments on performance of broiler chicks during experimental growth period (35 days of age)

\begin{tabular}{|c|c|c|c|c|c|c|}
\hline Treatment & $\begin{array}{c}\text { BW } \\
\text { (g at } 5 \\
\text { weeks) }\end{array}$ & $\begin{array}{c}\text { BWG } \\
\text { (g/bird from } \\
\text { 1-5 weeks) }\end{array}$ & $\begin{array}{c}\text { FI } \\
\text { (g/bird from } \\
\text { 1-5 weeks) }\end{array}$ & $\begin{array}{c}\text { FCR } \\
\text { (g feed : } \\
\text { g gain) }\end{array}$ & $\begin{array}{c}\text { Mortality } \\
(\%)\end{array}$ & $\begin{array}{c}\text { European } \\
\text { production } \\
\text { efficiency factor }\end{array}$ \\
\hline $\mathrm{T} 1$ & $1918.04^{d}$ & $1870.42^{d}$ & 3201.22 & $1.71^{\mathrm{a}}$ & $3.70^{\mathrm{a}}$ & $309.31^{\mathrm{e}}$ \\
\hline $\mathrm{T} 2$ & $1988.93^{\mathrm{cd}}$ & $1940.86^{\mathrm{cd}}$ & 3126.52 & $1.61^{\mathrm{ab}}$ & $3.37^{\mathrm{ab}}$ & $340.88^{\mathrm{bcd}}$ \\
\hline T3 & $1917.50^{\mathrm{d}}$ & $1868.83^{d}$ & 3053.52 & $1.63^{\mathrm{ab}}$ & $3.43^{\mathrm{ab}}$ & $323.80^{\text {de }}$ \\
\hline $\mathrm{T} 4$ & $1977.96^{\mathrm{cd}}$ & $1930.24^{\mathrm{cd}}$ & 3170.46 & $1.64^{\mathrm{a}}$ & $3.51^{\mathrm{a}}$ & $331.98^{\text {cde }}$ \\
\hline $\mathrm{T} 5$ & $1922.14^{\mathrm{d}}$ & $1873.65^{\mathrm{d}}$ & 3107.48 & $1.66^{\mathrm{a}}$ & $3.53^{\mathrm{a}}$ & $319.44^{\mathrm{e}}$ \\
\hline T6 & $2087.59^{\mathrm{a}}$ & $2039.85^{\mathrm{a}}$ & 3129.17 & $1.53^{b}$ & $3.11^{\mathrm{b}}$ & $376.73^{\mathrm{a}}$ \\
\hline $\mathrm{T} 7$ & $2070.83^{a b}$ & $2022.51^{\mathrm{ab}}$ & 3116.50 & $1.54^{\mathrm{b}}$ & $3.14^{b}$ & $371.92^{a b}$ \\
\hline T8 & $1983.28^{\mathrm{cd}}$ & $1935.21^{\mathrm{cd}}$ & 2967.93 & $1.53^{b}$ & $3.12^{b}$ & $357.95^{a b c}$ \\
\hline T9 & $2009.11^{b c}$ & $1960.94^{b c}$ & 2996.92 & $1.53^{b}$ & $3.09^{b}$ & $363.99^{a b c}$ \\
\hline SEM & 8.40 & 8.39 & 24.25 & 0.02 & 0.05 & 5.44 \\
\hline P-value & 0.001 & 0.003 & 0.347 & 0.001 & 0.002 & 0.000 \\
\hline Sig. & $* * *$ & $* * *$ & NS & $* * *$ & $* *$ & $* * *$ \\
\hline
\end{tabular}

T1= Control, T2= Melittin $(83.3 \mu \mathrm{g} / \mathrm{L}), \mathrm{T} 3=$ Melittin $(166.6 \mu \mathrm{g} / \mathrm{L}), \mathrm{T} 4=$ Thepax $(0.25 \mathrm{~g} / \mathrm{kg}), \mathrm{T} 5=$ Thepax $(0.5 \mathrm{~g} / \mathrm{kg}), \mathrm{T} 6=$ Melittin $(83.3 \mu \mathrm{g} / \mathrm{L})+$ Thepax $(0.25 \mathrm{~g} / \mathrm{kg}), \mathrm{T} 7=$ Melittin $(166.6 \mu \mathrm{g} / \mathrm{L})+$ Thepax $(0.25 \mathrm{~g} / \mathrm{kg}), \mathrm{T} 8=\operatorname{Melittin}(83.3 \mu \mathrm{g} / \mathrm{L})+$ Thepax $(0.5 \mathrm{~g} / \mathrm{kg}), \mathrm{T} 9=$ Melittin $(166.6 \mu \mathrm{g} / \mathrm{L})+$ Thepax $(0.5 \mathrm{~g} / \mathrm{kg})$

$\mathrm{BW}=$ body weight, $\mathrm{BWG}=$ body weight gain, $\mathrm{FI}=$ feed intake, $\mathrm{FCR}=$ feed conversion ratio abc, Letters in the same column with different superscripts are significantly different.

$\mathrm{SEM}=$ standard error means, NS $=$ Non-signifiant, $* *=\mathrm{P} \leq 0.01, * * *=\mathrm{P} \leq 0.001$ 
Table (4): Effect of different inclusion types and levels of non-traditional additives as replacement of commercial antimicrobial and antiviral treatments on carcass and internal organs relative weights (\%) of broiler chicks at the end of experimental period (35 days of age)

\begin{tabular}{|l|c|c|c|c|c|c|c|c|}
\hline Treatment & $\begin{array}{c}\text { Carcass } \\
(\%)\end{array}$ & $\begin{array}{c}\text { Liver } \\
(\boldsymbol{\%})\end{array}$ & $\begin{array}{c}\text { Gizzard } \\
(\boldsymbol{\%})\end{array}$ & $\begin{array}{c}\text { Heart } \\
(\boldsymbol{\%})\end{array}$ & $\begin{array}{c}\text { Spleen } \\
(\boldsymbol{\%})\end{array}$ & $\begin{array}{c}\text { Bursa } \\
(\boldsymbol{\%})\end{array}$ & $\begin{array}{c}\text { Abdominal } \\
\text { fat }(\boldsymbol{\%})\end{array}$ & $\begin{array}{c}\text { Intestinal } \\
\text { length } \\
(\mathbf{c m})\end{array}$ \\
\hline T1 & $70.85^{\mathrm{d}}$ & 2.33 & 1.48 & 0.55 & 0.13 & $0.13^{\mathrm{d}}$ & $1.52^{\mathrm{a}}$ & 201 \\
T2 & $72.43^{\mathrm{bcd}}$ & 2.38 & 1.53 & 0.72 & 0.12 & $0.17^{\mathrm{c}}$ & $0.83^{\mathrm{b}}$ & 198 \\
T3 & $73.16^{\mathrm{bc}}$ & 2.60 & 1.57 & 0.58 & 0.16 & $0.21^{\mathrm{ab}}$ & $0.70^{\mathrm{b}}$ & 198 \\
T4 & $71.61^{\mathrm{cd}}$ & 2.57 & 1.66 & 0.67 & 0.12 & $0.13^{\mathrm{d}}$ & $1.16^{\mathrm{ab}}$ & 209 \\
T5 & $72.71^{\mathrm{bcd}}$ & 2.46 & 1.47 & 0.67 & 0.14 & $0.14^{\mathrm{d}}$ & $1.03^{\mathrm{ab}}$ & 201 \\
T6 & $74.36^{\mathrm{ab}}$ & 2.43 & 1.51 & 0.60 & 0.11 & $0.18^{\mathrm{b}}$ & $0.66^{\mathrm{b}}$ & 180 \\
T7 & $75.24^{\mathrm{a}}$ & 2.23 & 1.51 & 0.53 & 0.10 & $0.20^{\mathrm{ab}}$ & $0.58^{\mathrm{b}}$ & 186 \\
T8 & $73.51^{\mathrm{abc}}$ & 2.33 & 1.72 & 0.73 & 0.16 & $0.19^{\mathrm{b}}$ & $0.62^{\mathrm{b}}$ & 198 \\
T9 & $73.89^{\mathrm{ab}}$ & 2.50 & 1.74 & 0.68 & 0.15 & $0.24^{\mathrm{a}}$ & $0.58^{\mathrm{b}}$ & 192 \\
SEM & \pm 0.31 & \pm 0.03 & \pm 0.04 & \pm 0.02 & \pm 0.01 & \pm 0.01 & \pm 0.08 & \pm 3.33 \\
P-value & 0.001 & 0.179 & 0.759 & 0.213 & 0.765 & 0.034 & 0.001 & 0.750 \\
Sig. & $* * *$ & NS & NS & NS & NS & $*$ & $* * *$ & NS \\
\hline
\end{tabular}

abc, Letters in the same column with different superscripts are significantly different.

$\mathrm{T} 1=$ Control, T2= Melittin $(83.3 \mu \mathrm{g} / \mathrm{L}), \mathrm{T} 3=$ Melittin $(166.6 \mu \mathrm{g} / \mathrm{L}), \mathrm{T} 4=$ Thepax $(0.25 \mathrm{~g} / \mathrm{kg})$, T5= Thepax $(0.5 \mathrm{~g} / \mathrm{kg}), \mathrm{T} 6=$ Melittin $(83.3 \mu \mathrm{g} / \mathrm{L})+$ Thepax $(0.25 \mathrm{~g} / \mathrm{kg}), \mathrm{T} 7=$ Melittin $(166.6$ $\mu \mathrm{g} / \mathrm{L})+$ Thepax $(0.25 \mathrm{~g} / \mathrm{kg}), \mathrm{T} 8=$ Melittin $(83.3 \mu \mathrm{g} / \mathrm{L})+$ Thepax $(0.5 \mathrm{~g} / \mathrm{kg}), \mathrm{T} 9=$ Melittin $(166.6$ $\mu \mathrm{g} / \mathrm{L})+$ Thepax $(0.5 \mathrm{~g} / \mathrm{kg})$

$\mathrm{SEM}=$ standard error means, NS $=$ Non-signifiant, $*=\mathrm{P} \leq 0.05, * * *=\mathrm{P} \leq 0.001$ 


\section{A., Elmalky et al.}

Table (5): Effect of different inclusion types and levels of non-traditional additives as replacement of commercial antimicrobial and antiviral treatments on the chemical composition of broiler breast meat (\%) at the end of experimental period (35 days of age)

\begin{tabular}{|l|c|c|c|c|}
\hline Treatment & Moisture & Protein & Fat & Ash \\
\hline T1 & 71.03 & $24.53^{\mathrm{a}}$ & $2.93^{\mathrm{c}}$ & 1.28 \\
T2 & 72.00 & $21.97^{\mathrm{bcd}}$ & $3.20^{\mathrm{bc}}$ & 1.30 \\
T3 & 72.37 & $20.37^{\mathrm{e}}$ & $3.80^{\mathrm{a}}$ & 1.27 \\
T4 & 71.90 & $23.07^{\mathrm{b}}$ & $2.90^{\mathrm{c}}$ & 1.23 \\
T5 & 71.30 & $22.83^{\mathrm{bc}}$ & $2.77^{\mathrm{c}}$ & 1.27 \\
T6 & 71.20 & $22.67^{\mathrm{bc}}$ & $3.30^{\mathrm{bc}}$ & 1.27 \\
T7 & 71.93 & $21.33^{\mathrm{cde}}$ & $3.83^{\mathrm{a}}$ & 1.30 \\
T8 & 71.57 & $22.00^{\mathrm{bcd}}$ & $3.10^{\mathrm{bc}}$ & 1.37 \\
T9 & 71.63 & $20.90^{\mathrm{de}}$ & $3.67^{\mathrm{ab}}$ & 1.37 \\
SEM & \pm 0.13 & \pm 0.28 & \pm 0.09 & \pm 0.02 \\
P-value & 0.189 & 0.000 & 0.001 & 0.931 \\
Sig. & $\mathrm{NS}$ & $* * *$ & $* * *$ & NS \\
\hline
\end{tabular}

abc, Letters in the same column with different superscripts are significantly different.

$\mathrm{T} 1=$ Control, $\mathrm{T} 2=$ Melittin $(83.3 \mu \mathrm{g} / \mathrm{L}), \mathrm{T} 3=$ Melittin $(166.6 \mu \mathrm{g} / \mathrm{L}), \mathrm{T} 4=$ Thepax $(0.25 \mathrm{~g} / \mathrm{kg}), \mathrm{T} 5=$ Thepax $(0.5 \mathrm{~g} / \mathrm{kg}), \mathrm{T} 6=$ Melittin $(83.3 \mu \mathrm{g} / \mathrm{L})+$ Thepax $(0.25 \mathrm{~g} / \mathrm{kg}), \mathrm{T} 7=$ Melittin $(166.6 \mu \mathrm{g} / \mathrm{L})+$ Thepax $(0.25$ $\mathrm{g} / \mathrm{kg}), \mathrm{T} 8=$ Melittin $(83.3 \mu \mathrm{g} / \mathrm{L})+$ Thepax $(0.5 \mathrm{~g} / \mathrm{kg}), \mathrm{T} 9=$ Melittin $(166.6 \mu \mathrm{g} / \mathrm{L})+$ Thepax $(0.5 \mathrm{~g} / \mathrm{kg})$ $\mathrm{SEM}=$ standard error means, NS $=$ Non-signifiant, $\quad * * *=\mathrm{P} \leq 0.001$

Table (6): Economic evaluation of experimental treatments containing Melittin, Thepax or their combinations supplemented to broiler chicks throughout experimental growth period (1-35 days of age)

\begin{tabular}{|l|c|c|c|c|c|c|c|c|c|c|}
\hline Treatment & $\begin{array}{c}\text { Feed } \\
\text { intake } \\
\text { (kg) }\end{array}$ & $\begin{array}{c}\text { Price of } \\
\text { diet } \\
(\mathbf{L E} / \mathbf{k g})\end{array}$ & $\begin{array}{c}\text { Feed } \\
\text { cost }\end{array}$ & $\begin{array}{c}\text { BWG } \\
\mathbf{( k g )}\end{array}$ & $\begin{array}{c}\text { Selling } \\
\text { price }\end{array}$ & $\begin{array}{c}\text { Feed } \\
\text { cost/kg } \\
\text { gain }\end{array}$ & $\begin{array}{c}\text { Cost } \\
\text { index } \\
(\boldsymbol{\%})\end{array}$ & $\begin{array}{c}\text { Net } \\
\text { revenue }\end{array}$ & EE & $\begin{array}{c}\text { REE } \\
(\%)\end{array}$ \\
\hline T1 & 3.20 & 8.51 & 27.23 & 1.87 & 52.36 & 14.57 & 100.00 & 25.13 & 0.92 & 100.00 \\
T2 & 3.13 & 8.41 & 26.30 & 1.94 & 54.32 & 13.56 & 93.07 & 28.02 & 1.07 & 116.30 \\
T3 & 3.05 & 10.55 & 32.20 & 1.89 & 52.92 & 17.05 & 117.02 & 20.72 & 0.64 & 69.57 \\
T4 & 3.17 & 8.55 & 27.10 & 1.93 & 54.04 & 14.04 & 96.36 & 26.94 & 0.99 & 107.61 \\
T5 & 3.11 & 8.62 & 26.81 & 1.87 & 52.36 & 14.34 & 98.42 & 25.55 & 0.95 & 103.26 \\
T6 & 3.13 & 8.61 & 26.95 & 2.04 & 57.12 & 13.21 & 90.67 & 30.17 & 1.12 & 121.74 \\
T7 & 3.12 & 10.46 & 32.61 & 2.02 & 56.56 & 16.14 & 110.78 & 23.95 & 0.73 & 79.35 \\
T8 & 2.97 & 8.80 & 26.14 & 1.94 & 54.32 & 13.47 & 92.45 & 28.18 & 1.08 & 117.39 \\
T9 & 3.00 & 10.94 & 32.82 & 1.96 & 54.88 & 16.74 & 114.89 & 22.06 & 0.67 & 72.83 \\
\hline
\end{tabular}

$\mathrm{T} 1=$ Control, T2= Melittin $(83.3 \mu \mathrm{g} / \mathrm{L}), \mathrm{T} 3=$ Melittin $(166.6 \mu \mathrm{g} / \mathrm{L}), \mathrm{T} 4=$ Thepax $(0.25 \mathrm{~g} / \mathrm{kg}), \mathrm{T} 5=$ Thepax $(0.5$ $\mathrm{g} / \mathrm{kg}), \mathrm{T} 6=$ Melittin $(83.3 \mu \mathrm{g} / \mathrm{L})+$ Thepax $(0.25 \mathrm{~g} / \mathrm{kg})$, T7= Melittin $(166.6 \mu \mathrm{g} / \mathrm{L})+$ Thepax $(0.25 \mathrm{~g} / \mathrm{kg})$, T8= Melittin $(83.3 \mu \mathrm{g} / \mathrm{L})+$ Thepax $(0.5 \mathrm{~g} / \mathrm{kg}), \mathrm{T} 9=$ Melittin $(166.6 \mu \mathrm{g} / \mathrm{L})+$ Thepax $(0.5 \mathrm{~g} / \mathrm{kg})$

Price of diet=price of feed + price of Melittin or/and Thepax supplementation

Feed cost $=$ feed intake $\times$ price of $\mathrm{kg}$ diet

Selling price $=$ body weight gain $\times 28 \mathrm{~L} . \mathrm{E} / \mathrm{kg}$.

Cost index $=$ assuming feed cost $/$ gain of the control treatment equal 100

Net revenue $=$ selling price - feed cost

$\mathrm{EE}($ Economic efficiency $)=$ net revenue $/$ feed cost

REE (Relative economic efficiency) $=$ assuming the economic efficiency of the control treatment equal 100 


\section{REFERENCES}

Abdel-Raheem, S. M.; Abd-Allah, S.M.S.; and Hassanein, K.M.A., 2012. The effects of prebiotic, probiotic and synbiotic supplementation on intestinal microbial ecology and histomorphology of broiler chickens. IJAVMS, 6(4): 20-32.

Ahiwe, E.U.; Emenalom, O.O.; Etuk, E.B.; Okehie, U.N.; Odoemelam, V.U.; Uchegbu, M.C.; and Okenyi, C., 2015. Effect of broiler starter diet containing royal yeast additive on broiler starter performance and economic of production. Int. J. Agric. rural dev., 18(1): 2024-2028.

A.O.A.C. 2000. Official methods of analysis. Association of official analytical chemists. Washington, DC, USA.

Awad, W. A.; Ghareeb, K.; AbdelRaheem, S.; and Boh, J., 2009. Effects of dietary inclusion of probiotic and synbiotic on growth performance, organ weights, and intestinal histomorphology of broiler chickens. Poult. Sci., 88:49-56.

Bolarinwa, M.O.; Popoola, M.A.; Lijaduola, T.L.; and Sodeeq, A.E., 2013. Evaluation of the effect of bee venom administration on the serology and haematology of broiler chicken. Int. J. Appl. Sci. Engroment, 1(1):2324.

Boostani, A., Fard, M H R., Ashayerizadeh, A.; and Fshar, A.M., 2013. Growth Performance, Carcass yield and Intestinal Micro flora Populations of Broilers Fed Diets Containing Thepax and Yogurt. Braz. J. Poult. Sci., 15(1): 1-6.

Celik, K.; Denli, M.; Erturk, M.; Ozturkcan, O.; and Doran, F., 2001.
Evaluation of dry yeast

(Saccharomyces cerevisiae)

compounds in the feed to reduce alfatoxin B1 (AFB1) residues and toxicity to Japanese quails (coturnix coturnix Japonica). J. Appl. Anim. Res., 20: 245-250.

Duncan, D.B., 1955. Multiple range and multiple F-tests. Biometrics. 11, 1-42.

Fain, J.N.; Kabnick, K.S.; and ShihYing, L.I., 1981. Effects of melittin on adipocyte metabolism unrelated to lysophospholipid accumulation. Biochimica et Biophysica Acta, 677: 274-279.

Fox, J.L., 2013 Antimicrobial peptides stage a comeback. Nat. Biotech., 31: 379.

Ghadban, G.S., 2002. Probiotices in broiler production. A review. AlGhadbad Poultry Co. Ltd. Tulkum. Palestine, 66: 49-58.

Han, S.M.; Lee, K.G.; Yeo, J.H.; Kweon, H.Y.; Woo, S.O.; Lee, M.Y.; Baek, H.J.; and Park, K.K., 2010. Effect of venom from the Asian honeybee (Apis cerana Fab.) on LPSinduced nitric oxide and tumor necrosis factor- $\alpha$ production in RAW 264.7 cell line. J. Apic. Res., 45:131136.

Han, S.M.; Lee, K.G.; Park, K.K.; and Park, S.C., 2013. Skin sensitization study of bee venom (Apis mellifera L.) in guinea pigs and rats. Cutaneous Ocular Toxicol., 32(1): 27-30.

Jamasbi, E.; Batinovic, S.; Sharples, R.A.; Sani, M.; Robins, B.; Roy, M.; Wade, J.; Separovic, F.; and Hossain, M.A., 2014. Melittin peptides exhibit different activity on different cells and model membranes. Amino Acids, 46(12): 2759-2766.

Kannan, M.; Karunakaran, R.; Balakrishnan, V.; and Prabhakar, 
T.G., 2005. Influence of Prebiotics Supplementation on Lipid Profile of Broilers. Int. J. Poult. Sci., 4(12): 994997.

Kim, D.H.; Han, S.M.; Keum, M.C.; Lee, S.; An, B.K.; Lee, S.R.; and Lee, K.W., 2018. Evaluation of bee venom as a novel feed additive in fastgrowing broilers, British Poult. Sci., DOI:

10.1080/00071668.2018.1476675

Kim, G.B; Seo, Y.M.; Kim, C.H.; and Paik, I.K., 2011. Effect of dietary prebiotic supplementation on the performance, intestinal microflora, and immune response of broilers. Poult. Sci., 90 :75-82.

Lee, K.G.; Cho, H.J.; Bae, Y.S.; Park, K.K.; Choe, J.Y.; Chung, I.K.; Kim, M.; Yeo, J.H.; Park, K.H.; Lee, Y.S.; Kim, C.H.; and Chang, Y.C., 2009. Bee venom suppresses LPSmediated NO/iNOS induction through inhibition of PKC- $\alpha$ expression. J. Ethnopharmacol., 123:15-21.

Lemme, A.; Wijtten, P.J.A.; Van Wichen, J.; Petri, A.; and Langhout, D.J., 2006. Responses of male growing broilers to increasing levels of balanced protein offered as coarse or pellets of varing quality. Poult. Sci., 85(4): 721-730.

Liu, C.C., Hao, D.J., Zhang, Q., An, J., Zhao, J.J., Chen, B., Zhang, L.L.; and Yang, H., 2016. Application of bee venom and its main constituent melittin for cancer treatment. Cancer Chemotherapy

Pharmacology. 78 (6): 1113-1130

Midilli, M.; Alp, M.; Kocabağlı, N.; Muğlalı, Ö.H.; Turan, N.; Yılmaz, H.; and Çakır, S. 2008. Effects of dietary probiotic and prebiotic supplementation on growth performance and serum IgG concentration of broilers. South Afric. J. Anim. Sci., 38(1).

Mohanny, K.M., 2005. Investigations on propolis and bee venom produced by two Hybrids of honeybee with Reference to a New device for bee venom collection. Ph. D. Thesis, Faculty of Agriculture El- Fayoum, Cairo University, 142 pp.

Oliveira, R.F.; Mello, J.; Ferrari, F.B.; Souza, R.A.; Pereira, M.R.; Cavalcanti, E.; Villegas-Cayllahua, E.A.; Fidelis, H.A.; GiampietroGaneco, A.; Fávero, M.S.; Souza, P.A.; and Borba, H., 2021. Effect of Aging on the Quality of Breast Meat from Broilers Affected by Wooden Breast Myopathy. Animals, 11(7): 1960-1972.

Owens, B.; and McCracken, K.J., 2007. A comparison of the effects of different yeast products and antibiotic on broiler performance. British Poul. Sci., 48: 49-54.

Park, Y.K.; Lee, D.G.; Jang, S.H.; Woo, E.R.; Jeong, H.G.; Choi, C.H.; and Hahm, K.S., 2003. A Leu-Lysrich Antimicrobial Peptide: Activity and Mechanism. Biochimica Et Biophysica Acta - Proteins and Proteomics, 1645: 172-182.

Petracci, M.; Soglia, F.; Madruga, M.; Carvalho, L.; Elza, I.; and Estevez, M., 2019. Wooden-Breast, White Striping, and Spaghetti Meat: Causes, Consequences and Consumer Perception of Emerging Broiler Meat Abnormalities. Comprehensive Reviews in Food Sci. Food Saf., 18: 565-583.

Rabie, A.H.; El-Kaiaty, A.M.; Hassan, M.S.H.; and Stino, F.K.R., 2018. Influence of some honeybee products on some haematological and immunological parameters and meat 
Melittin, Thepax, Productive performance, Carcass quality, Broilers.

quality in broilers. Egypt. Poult. Sci. J., 38(2): 533-549.

Raghuraman, H.; and Chattopadhyay, A., 2007. Melittin: A membrane-active peptide with diverse functions. Biosci. Reports, 27(4-5): 189-223.

Regmi, S.; Choi, Y.H.; Choi, Y.S.; Kim, M.R.; and Yoo, J.C., 2017. Antimicrobial peptide isolated from Bacillus amyloliquefaciens K14 revitalizes its use in combinatorial drug therapy. Folia Microbiol 62(2):127-138.

Rodriguez, A.; Cuesta, A.; Ortuno, J.; Esteban, M.A.; and Meseguer, J., 2003. Immunostimulant properties of a cell wall-modified whole Saccharomyces cerevisiae strain administered by diet to sea bream (Sparus aurata L.). Vet. Immun. Immunopathol., 96:183-192.

Santoso, U.; Tanaka, K.; and Ohtanis, 1995. Effect of dried Bacillus subtilis culture on growth, body composition and hepatic lipogenic enzyme activity in female broiler chicks. British J. Nutr., 74: 523-529.
SAS Institute, 2004. SAS Software 9.0

ed. SAS Institute Inc, Cary, NC

Schmidt, M.; Hafner, M.; and Frech, C., 2014. Modeling of salt and $\mathrm{pH}$ gradient elution in ion-exchange chromatography. J. Sep. Sci., 37: 5-13.

Sun, D.J.; Lee, J.W., Lee, Y.H., Song, H.S.; and Hong, J.T., 2007. "Therapeutic application of antiarthritis, pain-releasing and anti-cancer effects of $\mathrm{BV}$ and its constituent compounds". Pharmacology and Therapeutics 115: 246-270.

Wang, G.; Li, X.; and Wang, Z., 2016. APD3: Antimicrobial peptide Database as a Tool for research and education. Nucl. Acids Res., 44: 10871093.

Webb, E.C., 2006. Manipulating beef quality through feeding. South Afric. Anim. Sci., 7: 5-15.

Willyard, C., 2017. The drug-resistant bacteria that pose the greatest health threats. Nature, 543: 15. 


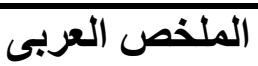

\section{تأثير الميليتين والثيباكس كبدائل طبيعية للمعاملات الدوائية المضادة للميكروبات والفيروسات

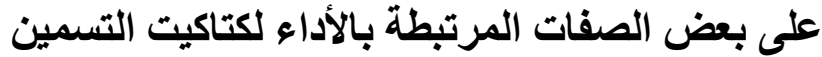

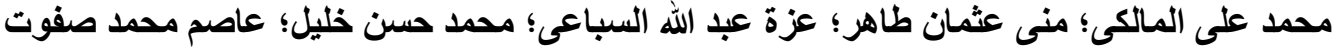

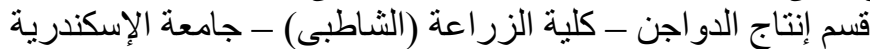

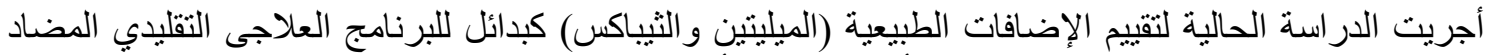

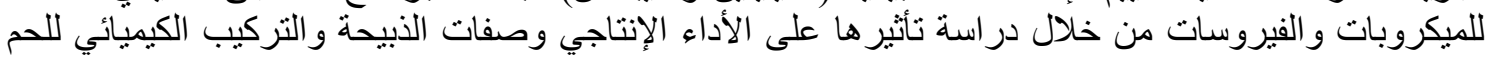

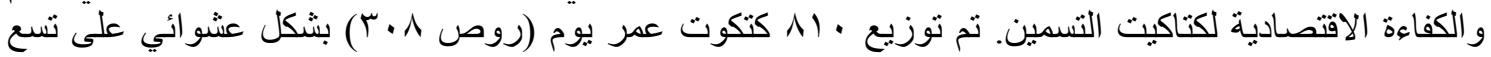

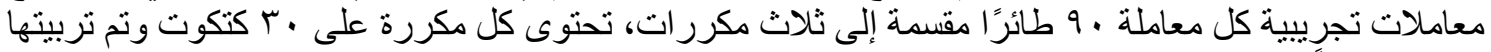

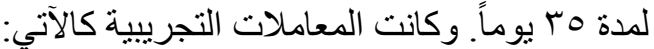

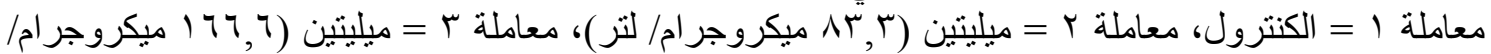

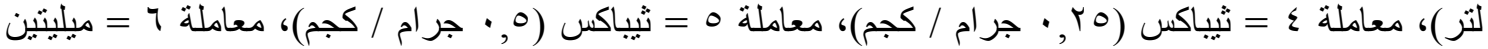

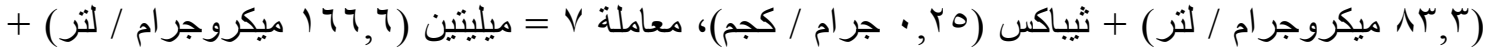

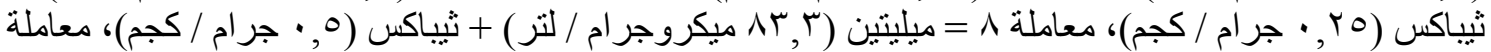

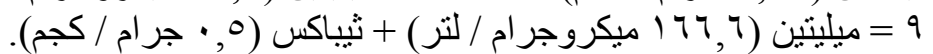

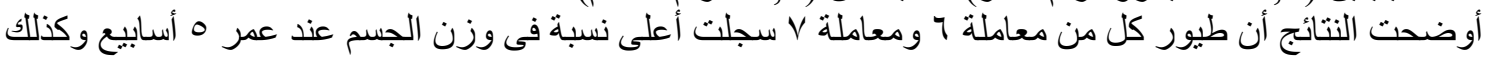

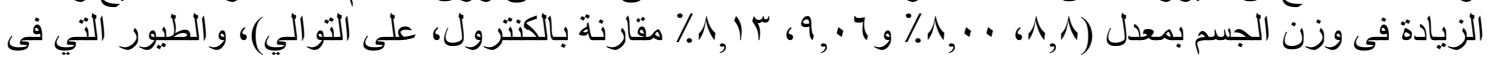

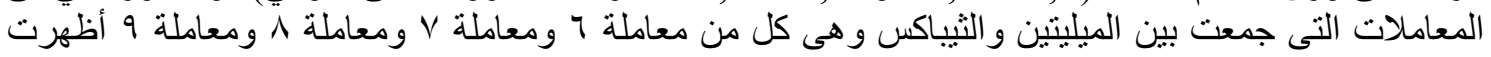

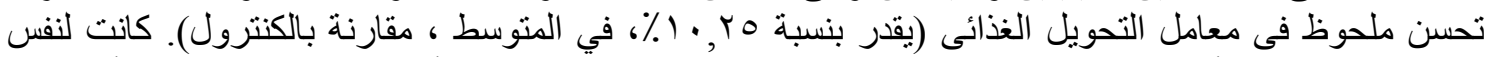

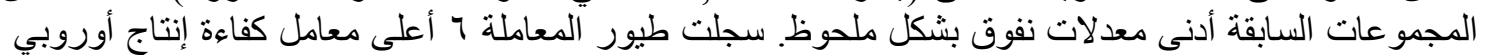

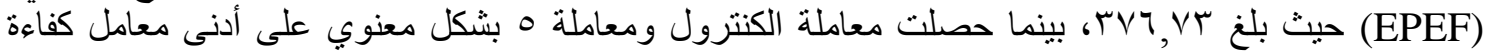

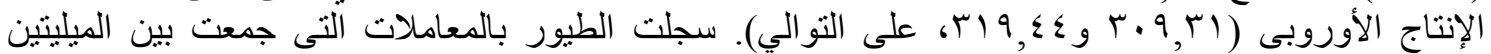

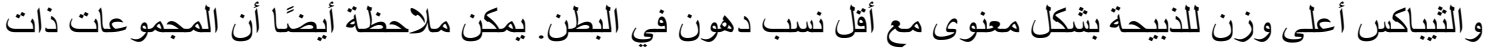

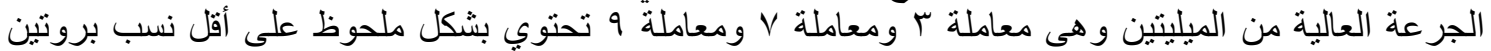

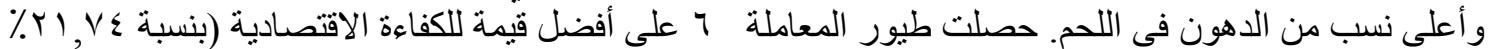

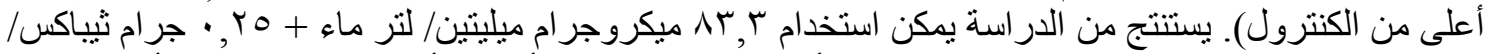

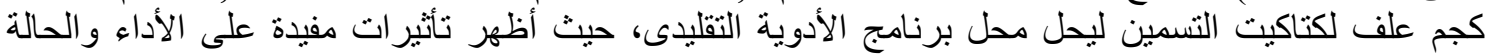
الصحية وجودة الذبيحة لاجاج اللحم مع تحسين الكفاءة الاقتصادية من إنتاج دجاج التئل التسمين. 